VERSITA

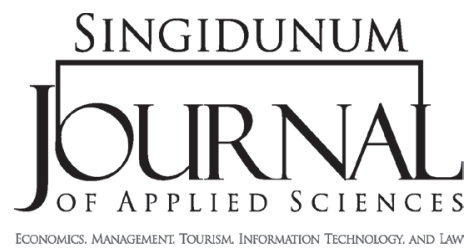

SINGIDUNUM JOURNAL 2013, 10 (2): 7-18

ISSN 2217-8090

UDK 336.761(497.6)

DOI 10.5937/sjas10-4713

Original paper/Originalni naučni rad

\title{
POSSIBILITY OF APPLYING ECONOMIC VALUE ADDED IN THE CAPITAL MARKET OF THE REPUBLIC OF SRPSKA
}

\author{
Almir Alihodžić1, ${ }^{*}$ \\ ${ }^{1}$ University of Zenica, Faculty of Economics \\ 1 Travnička Street, Zenica, Bosnia and Herzegovina
}

\begin{abstract}
:
The efficiency of a management team primarily depends on the level of improvement of enterprise performances, i.e. whether its market value has increased or whether it creates value for shareholders. The accounting net profit can provide a partial answer to this question because it covers only one portion of the cost of capital, i.e. the cost of debt capital, while the price and cost of equity are disregarded. The method of the economic value added takes into account an average cost of capital, i.e. it calculates the total costs of borrowed capital and own capital. This paper explores the possibility to calculate economic value added for an individual share within the share market index of BIRS.
\end{abstract}
Key words:
shareholder value added, economic value added, cost of capital, capital market.

\section{INTRODUCTION}

A competitive advantage represents a position of a company with a reference to a company with the same activities. In this context, the competitive advantage must be evaluated according to different activities. Also, approaches to different competitive advantages are different, such as: the cost -benefit of marketing and price, advantage of recognized quality, superior organizational skills, etc. A company is considered successful if it continually monitors and investigates the possibility of increasing the yield, so that only a series of short-term benefits can maintain an overall competitive advantage. Attractiveness of a business and competitive advantage are the main sources of enterprise value creation (Wachowicz and Van Horne, 2007).

Recently, the development of new performance measures has occurred, as well as the development of new performance measurement systems. The basic idea regarding the development of new performance measures is reflected in the fact that internal accounting standards represent imperfect substi- tutes for new internal standards that would have a higher correlation with market performance, i.e. with the target function of maximising shareholder value. The growth of an accounting standard can be achieved when a management team invests below the average cost of capital, while shareholder value is created if the company achieves on invested assets, which is a rate of return above the cost of capital.

A business value (valuation) of a capital project or any proposed investment is the function of an amount, timing and uncertainty of future cash flows. Therefore, managers should not only invest, but also manage. Measuring the success of a business is based on the measurement of previous data, of what has been accomplished, and not what is yet to be achieved. The question is: How to ensure that a business performance measurement system used by a company is in compliance with the principles that lead to the creation of value? Or rather, how to provide a connection between the historical evaluation of performances and evaluation oriented towards the future? 
Assistance should be sought in value standards of performance and performance systems or models to create value for shareholders. The best-known criteria for evaluating a company performance are:

1. Shareholder Value Added - SVA,

2. Economic Value Added - EVA and

3. Cash Value Added - CVA.

The main objective of this paper is to calculate economic value added for individual actions within the stock market index of BIRS and to determine the relationship between the Economic Value Added and net profit of a company. This paper is organized as follows. The first part describes the given concept of the Economic Value Added. The second part deals with financial and market indicators in the capital market of Bosnia and Herzegovina putting special emphasis on the capital market of the Republic of Srpska. The final part includes the calculation of the Economic Value Added for particular shares listed on the the Banja Luka Stock Exchange (BLSE).

\section{SHAREHOLDER VALUE ADDED}

The originator of performance value measures is Alfred Rappaport, a professor at the Northwestern University of Illinois, who developed and introduced the SVA in 1986. The essence of the Rappaport's shareholder value approach is the ultimate goal of systematic unpacking corporations - maximizing shareholder value through variables affecting a given value of the value drivers. According to Rappaport, the total value of a company consists of:

1. the present value of future free cash flow projections for the period ${ }^{1}$,

2. current residual value of the company and

3. current value of cash, marketable securities and other investment companies that can be converted into cash.

A free cash flow represents the remaining net cash flow from operating activities after it undergoes all necessary settlement issues in an investment activity. Free cash flows can be freely distributed to the investors in a financial activity without the risk of affecting the business outlook of companies (Table 1).

1 Discounting is carried out using the Weighted-Average Cost of Capital of companies - WACC.

\begin{tabular}{ll}
\hline No. & \multicolumn{1}{c}{ Description } \\
\hline 1. & Revenues from Sales \\
\hline 2. & Operating Expenses \\
\hline 3. & Earnings before Interest and Taxes (EBIT) - (1-2) \\
\hline 4. & Taxes \\
\hline 5. & Net Operating Profit after Tax (NOPLAT) - (3-4) \\
\hline 6. & Investment in Permanent Working Capital \\
\hline 7. & Incremental Investments in Fixed Assets \\
\hline 8. & Depreciation Expenses \\
\hline 9. & Free Cash Flow for Investors (5-6-7-8) (FCFF) \\
\hline
\end{tabular}

Table 1: Calculation of FCFF

Given that the total market value of a company is the sum of values of debt and equity, shareholder value represents the difference between the total value of a company and the market value of debt. Thus, the added value for shareholders (SVA) represents the measure of change in shareholder value over time, i.e. difference in shareholder value at the end of the year as well as shareholder value at the beginning of the year.

The Rappaport's model of value creation includes the following:

1. rate of sales growth,

2. growth rate of business profit,

3. corporate tax rate,

4. working capital investment,

5. capital investments,

6. cost of capital of a company, and

7. value growth duration.

The first three indicators refer to business decisions, such as: decisions about product mix, pricing, promotion, distribution and customer service, as well as efforts to save on manufacturing and non-manufacturing costs. In the fourth and fifth value indicator, investment decisions are embedded, while the cost of capital depends on financial decisions. The indication of the value growth duration is very important for the simple reason that the company will realize the value if the rate of return on capital is higher than the cost of the company. If a company does not achieve the rate of return that is higher than the cost of capital, the company will destroy its values, as well as shareholder value. Value drivers are very important as they enable the top 


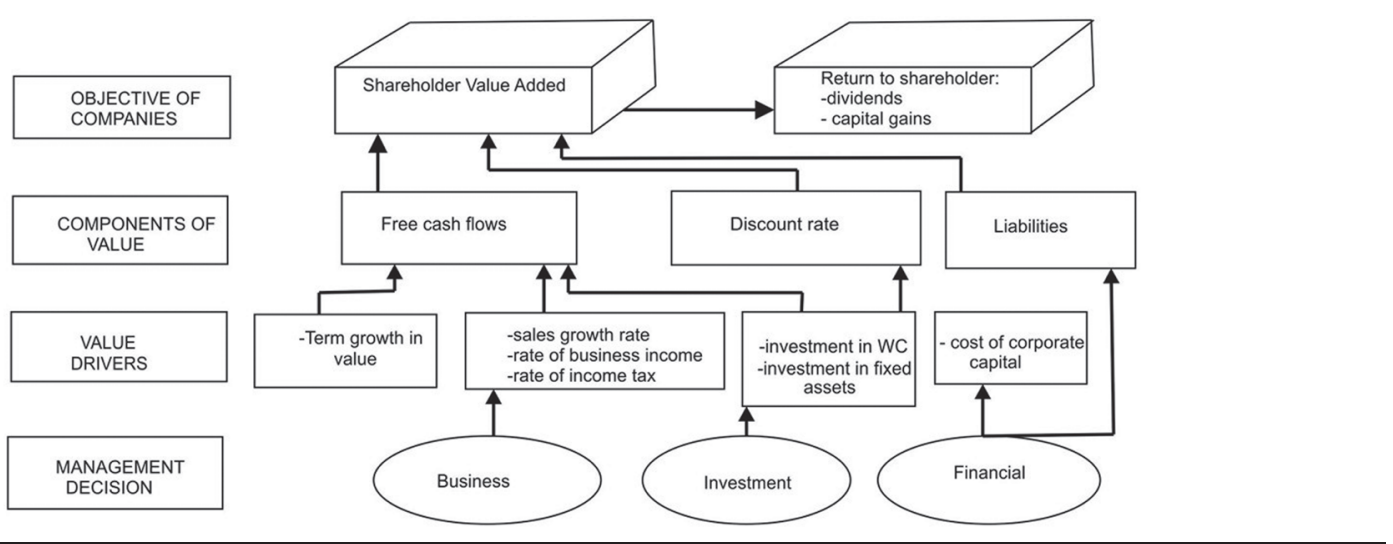

Figure 1: The Rappaport's Shareholder Value

Source: Rappaport, A. (1998)

management to be aware of the important factors of values, to set targets for the drivers and monitor and measure the achievement on the basis of comparisons with target sizes, as well as competition in the industry. Figure 1 illustrates a shareholder value network (Rappaport, 1998).

\section{ECONOMIC VALUE ADDED}

The Economic Value Added, as the result of an economic value of property, is registered and protected by Stern Stewart \& Co. consulting company in the United States. The idea of this particular EVA is not entirely new. The application of Economic Value Added - EVA goes back to the early 1920s in the company of General Motors, where the Stern Stewart \& Co. consulting company defined the EVA as the net operating profit minus the opportunity cost of the total capital invested in the company. Thus, the EVA can be defined as the estimate of an actual economic profit, for which earnings will exceed or be lower than the required minimum rate of return that shareholders could achieve by investing in other securities of the same degree of risk. The basic EVA model is a restructured residual income model. The residual income is the measure of success and it is based on the idea that the real profit for shareholders is a part of the return on capital in excess of the expected return.

The EVA is obtained by deducting the total invested capital from the profit after tax, i.e. one's own and others'. If the result is positive, it means that the company generates additional economic value for shareholders, and if it is negative, the company is eating its substance (Belak, 1997).

\section{CALCULATION OF ECONOMIC VALUE ADDED}

Unlike accounting profit, the EVA is a real economic profit remaining after covering the cost of debt and shareholder principal. The main difference between the EVA and accounting profit is that the EVA measures the economic profit, i.e. residual income tailored to the specific accounting profit with correctional situations in accordance with generally accepted accounting principles - GAAP. Stern Stewart identified 164 possible corrections of an accounting value related to an operating profit and invested capital. The most important accounting corrections are:

1. capitalization of research and development costs;

2. capitalization of marketing costs related to new brands, entering new market, increasing market share, etc.;

3. introduction of cash operating taxes obtained when an increase in deferred taxes is deducted from income tax and tax benefit from tax free interest costs is added;

4. capitalization of operating lease costs;

5. provisions for doubtful receivables and guarantees;

6. inclusion of one-off cost of restructuring;

7. inclusion of goodwill amortization;

8. replacement of accounting depreciation with economic depreciation. In order to calculate the economic value added, we need the following three sizes:

Size of the profit, i.e. net operating profit after taxes - NOPLAT (Belak, 2002); 
Invested capital assets used in operations of the company reduced by the amount of an interest free short term obligation, and Cost of capital, which is the minimum profitability that is necessary to meet expectations of the owners and creditors of a company as a compensation for the risk, i.e. a marginal rate required for creating value.

The basic formula for the EVA is:

$$
E V A=\text { NOPLAT }_{\text {corrected }}-(\text { cost of capital } \times \text { invested capital) }
$$

Also, there are two approaches to defining the EVA, namely:

1. accounting and

2. financial.

The accounting principle defines the EVA as the difference between net operating profit after taxes (NOPLAT) and their weighted average cost of capital.

$$
E A_{t}=\text { NOPLAT }_{t}-\left(I C_{(t-1)} \times W A C C\right)
$$

Where:

NOPLAT $_{t}$ - is net operating profit after tax in year t. IC - is invested capital

WACC - is weighted average of capital

Or as:

NOPLAT $=E B I T(1-t)$

Where:

EBIT is earnings before interest and taxes, and $\mathrm{t}$ - is tax rate

By substituting the formula (3) with formula (2) we obtain:

$$
\mathrm{EVA}_{\mathrm{t}}=\mathrm{EBIT}_{\mathrm{t}}(1-\mathrm{t})-\left(\mathrm{IC}_{\mathrm{t}-1} \times \mathrm{WACC}\right)
$$

As we may see, the EVA is equal to NOPAT ${ }^{2}$, reduced by the cost of invested capital. The EVA in the accounting categories can be expressed as the difference between the rate of return on capital and the cost of capital rate multiplied by the invested capital. Therefore, in order to ensure an economic benefit, a company must achieve a return higher than the rate of the cost of capital at an appropriate scale to realize this capital. Likewise, the EVA can be expressed as follows (Narayanan and Nanda, 2007):

EVA $=(\%$ return of capital $-\%$ cost of capital $) \times$ invested capital

2 NOPAT is net operating profit for tax, while the cost of an invested capital is equal to the invested capital multiplied by the WACC.
If a return on invested capital is expressed as ROIC and cost of capital as a weighted average cost of capital (WACC), we obtain:

$E V A=\left(R O I C_{t}-W A C C\right) \times I C_{t-1}$

Therefore, it follows that:

$$
\text { ROIC }_{t}=\frac{\text { NOPLAT }}{I C_{t-1}}
$$

Based on formula (7), it can be concluded that the EVA will be positive as long as the return on capital exceeds the invested cost of capital. When the EVA is negative, the value of the company decreases, as business income cannot cover the total cost of capital. A company with a negative EVA may also have a positive financial result, which means that returns required by certain foreign investors are met, but not the interest of shareholders, i.e. EVA can be increased by increasing the following:

1. if ROIC increases, while the invested capital and WACC are constant;

2. faster growth of ROIC than the WACC, also resulting in the increase of EVA;

3. divestment activities with no added value. If a reduction in capital is more than offset by an improvement in the spread between ROIC and WACC, the EVA increases;

4. longer period in which it is expected that the ROIC is higher than WACC;

5. reduction in the cost of capital.

\section{ADVANTAGES AND DISADVANTAGES OF ECONOMIC VALUE ADDED}

A certain number of global companies use the concept of economic value added for making capital investment decisions, as well as for measuring their performance. A number of managers from a list of 500 companies published by the Fortune Magazine together with Stern Stewart use this concept. It is assumed that the concept of economic value added associates the development strategy of a company and its long-term investments with the expectations of owners to increase their value. The economic value added can be calculated not only for a company as a whole, but for each individual investment. On the basis of a given budget, decisions on a gradual disinvestment in certain parts of a company or individual projects can be made. The main advantage of performance value measurements is reflected in the 
fact that they show how managers can create value and what the main value drivers are.

An important advantage of economic value added is reflected in the fact that it expresses a performance of current business activities in absolute rather than relative terms, such as the rate of return on invested capital. Since the economic value added is the measure of real earnings, it expresses a result more accurately than reported accounting net profit, as it respects the overall cost of capital, i.e. debt and equity. Therefore, the economic value added increases a payment reference effect on the success of business enterprises compared to net earnings per share, which is calculated on the basis of cost of debt capital. In addition to being a good measure for performance measurement, it is also used as the basis for calculating premiums for managers (Ivanišević, 2010, pp. 308-309).

Apart from these advantages, the concept of economic value added involves certain disadvantages. Namely, one disadvantage is an amount of an invested capital to book value, which is a problem especially for companies that make large investments in research and development, which are expected to bring benefits in the long run. The given problem and other issues related to book value are eliminated to some extent by certain adjustments, such as for research and development costs on the basis of cost of materials using the LIFO method, posting specific provision for deferred costs, etc. As the economic value added refers to the current yield, it is assumed not to be significantly used for planning and assessing cost-effectiveness of a new capital investment, such as the net present value (NPV), which is used as a criterion for an average cost of capital.

\section{PRICE CALCULATION AND WEIGHTED AVERAGE COST OF CAPITAL}

A cost of capital is a discount rate, based on which discount cash flow factor and residual value are determined. The cost of capital in literature is often found by the name of a cost of capital or opportunity cost of capital, which needs to provide a rate of return on capital that would be formed from an alternative investment capital. In order to achieve this, the cost of capital also includes the risk of achieving a rate of return. There are two types of risks (Rodić and Filipović, 2010):

1. systematic risk and

2. non-systematic risk.
The systematic risk includes factors arising from an economic and political environment, such as: changes in exchange rates, fluctuations in raw material prices, inflation, tax reform, changes in the cost of salary levels, etc. These are general market risks that company management cannot influence and they cannot be avoided by investors who diversify investments within the national economy. Therefore, systematic risks are ignored in determining the cost of capital.

Unsystematic risks are individual risks, varying from company to company, and they are influenced by several factors: market position, competitiveness of own products in the market, degree of dependence on customers, suppliers and creditors, negative reports in the press, yielding, property and financial position. Unsystematic risks cannot be eliminated by changing the owners and company management.

Their elimination takes time and, among other things, they are conditioned by inventiveness and creativity of the company management. In theory and practice, the cost of capital is determined by:

- Relative Risk Premium, or

- Capital Asset Pricing Model.

The relative risk premium in literature is often found by name of the method of masonry. The essence of the method is to first determine the real rate of return on risk free investments. ${ }^{3}$ A premium rate for each investment risk in the company estimated is added to a real rate of return. The Capital Asset Pricing Model is based on the fact that investors with assets at risk require additional expected revenue, i.e. releasing rate risk as a compensation for holding assets that carry risk. The essence of the model is the following: for example, in a period of 5 years, the rate of return on equity is compared to the rate of return in the market. If a rate of return on equity varies more, the risk is higher and vice versa, if the rate of return on equity varies less, the risk is lower.

A relative variation degree of yield in statistics is called the beta coefficient. It is calculated as a ratio between an actual rate of return on equity of an observed company and a real rate of return on equity in the market. If the beta coefficient is equal to 1 , it means that the rate of return on equity of the observed company varies identically with the rate of return on equity in the market. If beta is equal to 2 , it means that the rate of return on equity of the

3 The real rate of return on risk free investment is a rate achieved when purchasing government securities, such as bonds, reduced by the rate of inflation. 
observed company varies more than twice as much as the rate of return on equity in the market.

In countries with developed markets, such as the USA, for companies with shares, the rate of dividends on ordinary shares is taken as a return on equity, and a yield of corporation groups is taken as a return on equity over the entire market, included in the S\&P index. In our environment, a rate of return on equity of an observed company can be taken, as well as a rate of return on equity of a group of companies engaged in activities of a company estimated. When the beta coefficient is determined, a cost of capital $(\mathrm{K})$ for an observed company is determined using the following formula:

$$
K=k_{r p}+B\left(k_{m}-k_{r p}\right)
$$

where:

$\mathrm{k}_{\mathrm{rp}}$ - rate of return on equity for risk free investment;

$B$ - coefficienf of beta, and

$k_{m}$ - rate of return on equity of group of companies with the same business operations.

The Weighted Average Cost of Capital - WACC represents an average rate of return that a company must pay to shareholders and creditors. In most cases, it is an adjusted discount rate, adequate for the risk of cash flows of companies. A cost of capital depends on the risk of cash flow of companies. Also, a company is financed by borrowing or lending funds whether from banks, individuals or other sources. Companies pay interest to the borrowed amount, i.e. they pay the price of their debt, so their interest payments also contribute to the reduction of the tax base because it is recognized as an expense.
This cost of financing is called the cost of debt and it is marked with $r_{\mathrm{D}}(1-\mathrm{T})$ (Vukičević et al., 2010):

$W A C C=r_{E} \cdot \frac{E}{E+D}+r_{D}\left(1-T_{C}\right) \frac{D}{E+D}$

where:

$r_{E}$ - cost of capital of a company - i.e. return required by shareholders;

$r_{D}$ - cost of debt of a company - i.e. return required by lender;

E - market value of company's capital;

D - market value of debt of company, and

$\mathrm{T}_{\mathrm{c}}$ - company tax rate.

\section{FINANCIAL AND MARKET INDICATORS IN THE CAPITAL MARKET IN B\&H}

In 2011, in the B\&H capital market, there was a substantial increase in turnover on the Sarajevo Stock Exchange (SASE) and the Banja Luka Stock Exchange (BLSE), not accompanied by an increase of a market capitalization, which stood at $31.2 \%$ GDP. As can be see in Table 2 on the Sarajevo Stock Exchange, the market capitalization recorded a decrease in the value of $39.38 \%$ compared to 2010 , while the Banja Luka Stock Exchange recorded a marginal increase of $2.76 \%$ over the previous year. Also, a relative indicator of the market capitalization expressed as a percentage of GDP on the SASE and BLSE at the end of the year was $16.8 \%$ and $14.8 \%$ respectively, which represents a decrease by $12 \%$ in the SASE and $0.3 \%$ compared to BLSE in 2010 (Centralna banka Bosne i Hercegovine, 2011).

\begin{tabular}{|c|c|c|c|c|c|c|}
\hline \multicolumn{7}{|c|}{ Sarajevo Stock Exchange - SASE } \\
\hline Indicator & 2007 & 2008 & 2009 & 2010 & 2011 & Index \\
\hline 1 & 2 & 3 & 4 & 5 & 6 & $7(6 / 5)$ \\
\hline Turnover & 651,559 & 243,927 & 112,016 & 55,503 & 125,158 & $125.50 \%$ \\
\hline Number of Traded Securities & 70,773 & 17,116 & 19,632 & 76,338 & 56,693 & $(25.73 \%)$ \\
\hline Number of Transaction & 159 & 39 & 26 & 18 & 16 & $(11.12 \%)$ \\
\hline Market Capitalization & $7,934,359$ & $3,992,516$ & $3,660,174$ & $3,686,723$ & $2,234,863$ & $(39.38 \%)$ \\
\hline \multicolumn{7}{|c|}{ Banja Luka Stock Exchange - BLSE } \\
\hline Indicator & 2007 & 2008 & 2009 & 2010 & 2011 & Index \\
\hline 1 & 2 & 3 & 4 & 5 & 6 & $7(6 / 5)$ \\
\hline Turnover & 379,676 & 140,651 & 92,285 & 90,087 & 217,532 & $141.47 \%$ \\
\hline Number of Traded Securities & 765,213 & 506,993 & 81,462 & 161,633 & 215,756 & $33.48 \%$ \\
\hline Number of Transaction & 191 & 31 & 18 & 19 & 25 & $31.58 \%$ \\
\hline Market Capitalization & $3,961,413$ & $1,884,484$ & $1,920,689$ & $1,908,297$ & $1,961,022$ & $2.76 \%$ \\
\hline
\end{tabular}

Table 2: Exchange Transactions on SASE and BLSE for 2007 - 2011 (million EUR)

Source: www.cbbh.ba, Annual Report, 2011, p. 97 (Calculation by Author) 
In 2011, the four primary issues were successfully completed via SASE, namely: municipal bonds of the Municipality of Tešanj, the second issue of the issuer "Fad" Ltd Jelah -Tešanj and two issues of Federation of B\&H treasury bills in the amount of EUR 46,500,206. Regarding the quotation of bonds, the growth in 2011 amounted to EUR 11,823,422 or $21.67 \%$ of the total scheduled turnover, out of which the trade in FB\&H bonds of war claims amounted to EUR 5,546,359, with the total turnover of old foreign currency savings bonds of EUR 6,258,257, while the Brčko District bonds of old foreign currency savings were traded in the amount of EUR 18,805. In this market segment, in 3.751 transactions, the total of $44,295,874$ bonds were traded (Komisija za hartije od vrijednosti Republike Srpske, 2011, p. 16). With the investment fund index BIFX, an increase in the value by $1.36 \%$ has been recorded this year. The increase has been noted for the SASX-30 index, whose value increased by $2.66 \%$ over the previous year. The value of SASX-10 registered a decrease by $16.18 \%$ during the previous year (SASE, 2011).

An extremely rapid growth in sales and prices on the Banja Luka Stock Exchange until the first half of 2007 followed the trends of stock markets in neighbouring countries, where there were decline and stagnation activities after a while, as well as in a number of capital markets due to the global economic and financial crisis. The situation in the capital market of the Republic of Srpska in 2011 had similar characteristics as the markets of the countries in the region (Komisija za hartije od vrijednosti Republike Srpske, 2011, p. 5), taking into account the size and development of the market. As can be seen in Table 6, the overall turnover on the Banja Luka Stock Exchange in 2011 more than doubled compared to 2010, when it reached the value of EUR $217,532,701$, which was slightly above the turnover in 2006. The total market capitalization of all securities traded on the Banja Luka Stock Exchange as of 30 December 2011 amounted to EUR 1,961,022, which represents a relative increase by $2.76 \%$.

\begin{tabular}{cccc}
\hline Indices & $\begin{array}{c}\text { Last Day of } \\
\text { Previous } \\
\text { Period }\end{array}$ & $\begin{array}{c}\text { Last Day of } \\
\text { Period }\end{array}$ & \% Changes \\
\hline 1. BIRS & 956.12 & 876.36 & $(8.34 \%)$ \\
\hline 2. FIRS & $1,632.46$ & $1,822.07$ & $11.61 \%$ \\
\hline 3. ERS & 801.34 & 874.10 & $9.07 \%$ \\
\hline
\end{tabular}

Table 3: Index on BLSE in 2011

Source: www. blberza.com
As can be seen in Table 3, it is clear that the market index of BIRS registered a decrease by $8.34 \%$ in $2011 .{ }^{4}$ Unlike the BIRS, the stock index investment fund of the Republic of Srpska registered a relative increase by $11.61 \%$ compared to the same period in the previous year. The index of companies within the electric power system of the Republic of Srpska also registered a relative increase by $9.07 \%$ compared to the same period in the previous year.

\section{ASSUMPTIONS FOR APPLICATION OF ECONOMIC VALUE ADDED IN THE CAPITAL MARKET OF THE REPUBLIC OF SRPSKA}

It is necessary to have adjusted financial statements of certain companies listed on the Banja Luka Stock Exchange and an estimated cost of the capital rate in order to be able to apply the concept of the economic value added in the capital market of the Republic of Srpska. The companies for which the calculation possibility of economic value added for the capital market of the Republic of Srpska is to be examined are the first four companies included in the BIRS stock index with the highest percentage of participation in the structure of the stock market index. The research covered the period 2010 - 2011.

The economic theory implies that government securities are essentially free of systemic (default) risk and most analysts agree that government bonds are the best choice. However, the problem is in the selection of the maturity date. Some authors argue that short-term rate should be used, such as the interest rate, on quarterly government bonds. Others, however, claim that interest rates on long-term government bonds should be used, bearing in mind that investment projects are long-term (Wachowicz and Van Horne, 2008).

The following two important facts are usually asserted as evidence in favour of using rates on shortterm treasury notes: first, although nominal yield to maturity is guaranteed, actual yield can be under the influence of inflation per unknown rate; second, even government securities have certain risk, which is reflected in the yield curve which usually ascends over time reflecting higher liquidity risk of government bonds (Pike and Neale, 2009).

Desired yield to maturity (effective annual yield) - is return you expect to get if you buy bonds on the selected date and hold it to maturity, assuming that

4 The highest value of BIRS was on 8 April $2011(1,220.96$ points), and the lowest value was on 23 December 2011 (821.15 points). 
all future cash flows are reinvested at the same rate (compound interest account). The yield to maturity is calculated from the equation for calculating the price of bond. If we know the market price of bonds and cash flows of bonds payable in the future, we can calculate the yield to maturity. The yield to maturity can be defined as discount rate that equates the price of bond with the present value of the payment bond (Bodie et al., 2006). That is an average annual rate of return that will be achieved if the customer buys the bonds and bond holding to maturity, provided that all cash flows reinvested at a rate of return. This rate is often used in the reports from trading bonds to compare the yield of the bonds. Suppose that we know the price we pay for the bonds on the market, and that we receive cash flows from the bond (interest rate and the nominal value of bond). Calculation of the rate of return to maturity is reduced to searching unknown discount rate (r) that equates the left and the right side of equation (10), i.e. price equals the present value of bonds, and cash flows from bonds:

$\underset{\text { Ponds }}{\text { Price annuity }}=\frac{\mathrm{N}_{1}}{(1+r)^{1}}+\frac{\mathrm{N}_{2}}{(1+r)^{2}}+\ldots+\frac{\mathrm{N}_{n}}{(1+r)^{n}}$

\section{Where: \\ $\mathrm{N}$ - annuity; and \\ $r$ - discount rate}

According to Damodaran, risk premium in emerging markets with political risk, in countries of Eastern Europe and South America is estimated at 8.5\% (Damodaran, 2002, p. 49). This methodology, for those countries that are not free of default risk, estimates the risk-free rate for specific currency as a remainder between market rate on government bonds and premium for default risk of specific country, which is determined by credit rating of that specific country.

In this paper, we use ten-year municipal bonds issued by the Municipality of Bijeljina, which can be considered as equivalent to the bonds issued by the Government of Bosnia and Herzegovina. That rate was $6.75 \%$ and from it we subtracted an estimated premium for the default risk of our country that is $4.25 \%$ and thus we calculated the estimated nominal risk-free rate of BAM currency to be $2.5 \%{ }^{5}$

5 Bond issue of the Municipality of Bijeljina is in the nominal amount of 5.6 million EUR, and a nominal value per one bond is EUR. 51.13 The total number of bonds is 110,000
Companies that will be subject to the analysis of economic value added are:

1. Telekom Srpske, Banja Luka - TLKM - RA with $25 \%$ share in the structure of the BIRS index,

2. Hydroelectric Power Plants on the Drina River, Visegrad - HEDR - RA with 14.31\% share in the structure of BIRS index,

3. Hydroelectric Power Plants on the Trebišnjica River, Trebinje - HETR - R - A with 13.34\% share in the structure of the BIRS index and

4. Ugljevik a.d. Ugljevik with $7.17 \%$ share in the structure of the BIRS index. ${ }^{6}$

\section{CALCULATION OF ECONOMIC VALUE ADDED IN THE CAPITAL MARKET OF THE REPUBLIC OF SRPSKA}

The BIRS market index is a weighted index, which means that the share of individual stocks in the BIRS is determined by a market capitalization of each issuer. The market capitalization includes ordinary shares held by the public (free float). ${ }^{7}$ Maximum participation of each issuer in the BIRS on the date of the formation and revision is limited to $25 \%$. The BIRS is also a price index and does not include dividends paid in cash. Shares of 5 to 30 issuers can be included in the BIRS. The number of issuers whose shares are part of BIRS depends on the number of issuers that meet the requirements for the composition of BIRS (Table 4).

The value of the stock market index (BIRS) from 1 May 2004 to 16 November 2012 decreased by $16.28 \%$ and on 16 November 2012 the BIRS value amounted to 837.16 points. The BIRS index on 16 November 2012 included 20 companies with the following structure:

The companies that will be subject to the analysis of economic value added are:

1. Telekom Srpske, Banja Luka - TLKM - RA with $25 \%$ share in the structure of the BIRS index,

2. Hydroelectric Power Plant on the Drina, Visegrad - HEDR - RA with $14.31 \%$ share in the structure of BIRS index,

6 The issuer Nova banka, Banja Luka was not taken into consideration as the Banja Luka Stock Exchange statistics does not provide required financial ratios for the reporting period needed for further analysis.

7 The number of shares owned by the public shall not include shares held by shareholders who have over $10 \%$, except for investment funds and custody accounts. 


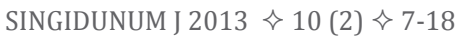

Alihodžić A. \& Possibility of applying economic value added

\begin{tabular}{cllrc}
\hline No & \multicolumn{1}{c}{ Symbol } & \multicolumn{1}{c}{ Issuer } & $\begin{array}{c}\text { Adjusted Number of Shares } \\
\text { (Participation in BIRS) }\end{array}$ & \% of BIRS \\
\hline 1. & TLKM-R-A & Telekom Srpske, Banja Luka & $72,639,797$ & $25.00 \%$ \\
\hline 2. & HEDR-R-A & Hidroelektrane na Drini, Višegrad & $14.31 \%$ \\
\hline 3. & HETR-R-A & Hidroelektrane na Trebišnjici, Trebinje & $154,682,609$ & $13.34 \%$ \\
\hline 4. & NOVB-R-E & Nova banka a.d. Banja Luka & $134,814,338$ & $11.43 \%$ \\
\hline 5. & RTEU - R-A & RiTE Ugljevik, Ugljevik & $70,863,294$ & $7.17 \%$ \\
\hline 6. & RITE-R-A & RiTE Gacko, Gacko & $89,600,091$ & $5.92 \%$ \\
\hline 7. & HELV-R-A & Hidroelektrane na Vrbasu, Mrkonjić Grad ${ }^{3}$ & $132,985,950$ & $3.62 \%$ \\
\hline 8. & BVRU-R-A & ZTC Banja Vrućica, Teslić & $35,824,669$ & $3.36 \%$ \\
\hline 9. & RFUM-R-A & Rafinerija ulja, Modriča & $28,309,803$ & $2.45 \%$ \\
\hline 10. & BOKS-R-A & Boksit, Milići & $49,546,129$ & $2.16 \%$ \\
\hline 11. & DEST-R-A & Hemijska industrija destilacije, Teslić & $11,104,138$ & $2.00 \%$ \\
\hline 12. & CIST-R-A & Cistoća, Banja Luka & $23,228,364$ & $1.56 \%$ \\
\hline 13. & EKBL-R-A & Elektrokrajina, Banja Luka & $6,722,728$, & $1.54 \%$ \\
\hline 14. & BIRA-R-A & Birač, Zvornik & $32,291,659$ & $1.49 \%$ \\
\hline 15. & ELDO-R-A & Elektro Doboj, Doboj & $314,949,484$ & $1.41 \%$ \\
\hline 16. & MRDN-R-A & Meridian, Banja Luka & $10,890,410$ & $0.84 \%$ \\
\hline 17. & RNAF-R-A & Rafinerije nafte, Brod & $5,740,628$ & $0.69 \%$ \\
\hline 18. & BLPV-R-A & Banjalučka pivara, Banja Luka & $52,586,489$ & $0.64 \%$ \\
\hline 19. & ELBJ-R-A & Elekro - Bijeljina, Bijeljina & $4,155,881$ & $0.64 \%$ \\
\hline 20. & KDVO-R-A & Dunav osiguranje, Banja Luka & $13,469,433$ & 0.42 \\
\hline
\end{tabular}

Table 4: Composition of BIRS Index

${ }^{1}$ Hydroelectric Power Plants on the Drina River, Visegrad; ${ }^{2}$ Hydroelectric Power Plant on the Trebišnjica River, Trebinje

${ }^{3}$ Hydroelectric power plants on the Vrbas River, Mrkonjić Grad

Source: www.blberza.com

3. Hydroelectric Power Plants on the Trebišnjica, Trebinje - HETR - R - A with $13.34 \%$ share in the structure of the BIRS index and

4. Ugljevik a.d. Ugljevik with $7.17 \%$ share in the structure of the BIRS index. ${ }^{8}$

The Table 5 illustrates financial indicators of Telecom Srpske, Hydroelectric Power Plants on the Drina, and Hydroelectric Power Plants on the Trebišnjica River, Inc Ugljevik, Inc. for 2010 and 2011.

Based on the research results of one part of the capital market in the Republic of Srpska and the structure of the most liquid companies included in the stock index of BIRS in 2010 and 2011, the following results of the analysis were obtained, i.e. the following amounts of economic value added and other financial indicators.

This research points to certain characteristics of selected corporate actions. Elaborated on the basis of the analysis, it can be concluded that the following companies made positive value added

8 The issuer Nova banka, Banja Luka was not taken into consideration as the Banja Luka Stock Exchange statistics does not provide required financial ratios for the reporting period needed for further analysis. in 2011:

1. the corporation of Telekom Srpske, Banja Luka achieved positive economic value added of EUR 96,732,339, which is a decrease in the relative amount of $2.58 \%$ and in the absolute amount of EUR 2,565,858 compared to 2010 , and

2. corporation Hydroelectric Power Plants on the Drina Inc. Visegrad, which in 2011 achieved positive economic value added of EUR. 1,297,777, which represents a relative decrease compared to the previous year by $80.84 \%$.

Other issuers observed in 2011 achieved a negative economic value added, despite the fact that they had a positive financial result, i.e. net profit.

The lowest, i.e. negative economic value added in 2011 was reported by hydroelectric power plants on the Drina River, Visegrad in EUR $(10,439,975)$. The joint stock companies which achieved a positive economic value added in 2010 are: Telekom Srpske Banja Luka Inc, and Hydroelectric Power Plants on the Trebišnjica Inc, while other issuers achieved negative values (Table 6). The results of this analysis suggest that the joint stock companies: 
(in EUR)

\begin{tabular}{|c|c|c|c|c|}
\hline \multirow[b]{2}{*}{ Financial Ratios } & \multicolumn{4}{|c|}{2010} \\
\hline & TLKM $-\mathrm{R}-\mathrm{A}$ & HEDR - R-A & HETR - R - A & RTEU-R-A \\
\hline 1. Return on Equity (ROE) & 15.37 & 1.98 & 1.78 & $(0.49)$ \\
\hline 2. Return on Assets (ROA) & 11.57 & 1.94 & 1.74 & $(0.43)$ \\
\hline 3. Earnings per Share (EPS) & 0.11 & 0.013 & 0.022 & - \\
\hline 4. Book value /Shares & 0.72 & 0.64 & 1.26 & 0.82 \\
\hline 5. EBITDA & $48.16 \%$ & $55.39 \%$ & $44.65 \%$ & $26.23 \%$ \\
\hline 6. The ratio of Market to Book Value & 1.15 & 0.34 & 0.17 & 0.23 \\
\hline 7. Dividend per Share (DPS) & 0.12 & 0.02 & 0.02 & - \\
\hline 8. P/E Ratio & 7.35 & 17.32 & 9.84 & - \\
\hline 9. $\mathrm{P} / \mathrm{S}$ Ratio & 1.67 & 4.46 & 2.55 & 0.83 \\
\hline 10. P/E 52W High & 7.39 & 21.35 & 12.28 & - \\
\hline 11. P/E 52W LoW & 14.09 & 17.20 & 9.50 & - \\
\hline \multirow[t]{2}{*}{ 12. Dividend Rate } & $14.17 \%$ & $4.62 \%$ & $5.56 \%$ & - \\
\hline & \multicolumn{4}{|c|}{2011} \\
\hline Financial Ratios & TLKM $-\mathrm{R}-\mathrm{A}$ & HEDR - R-A & HETR - R - A & RTEU-R-A \\
\hline 1. Return on Equity (ROE) & 11.49 & 0.22 & 0.02 & 2.61 \\
\hline 2. Return on Assets (ROA) & 11.92 & 0.21 & 0.02 & 2.25 \\
\hline 3. Earnings per Share (EPS) & 0.11 & 0.0014 & 0.0004 & 0.022 \\
\hline 4. Book value /Shares & 0.72 & 0.63 & 1.25 & 0.84 \\
\hline 5. EBITDA & $48.63 \%$ & $57.74 \%$ & $37.94 \%$ & $28.80 \%$ \\
\hline 6. The ratio of Market to Book Value & 1.14 & 0.35 & 0.18 & 0.23 \\
\hline 7. Dividend per Share (DPS) & 0.11 & - & - & 0.03 \\
\hline 8. P/E Ratio & 7.41 & 159.65 & $1,078.99$ & 8.78 \\
\hline 9. P/S Ratio & 1.66 & 9.06 & 3.73 & 0.66 \\
\hline 10. P/E 52W High & 7.46 & 196.78 & $1,345.62$ & 16.62 \\
\hline 11. P/E 52W LoW & 6.45 & 158.53 & $1,041.61$ & 9.34 \\
\hline 12. Dividend Rate & $13.09 \%$ & - & - & $9.34 \%$ \\
\hline
\end{tabular}

Table 5: Financial Ratios of Telekom Srpske, Hydroelectric Power Plants on the Drina, Hydroelectric Power Plants on the Trebišnjica River, Inc Ugljevik, Inc. for 2010 and 2011.

Source: www.blberza.com

(in million EUR)

\begin{tabular}{|c|c|c|c|c|c|}
\hline & & \multicolumn{4}{|c|}{2010} \\
\hline & Financial Ratios & TLKM $-\mathrm{R}-\mathrm{A}$ & HEDR - R-A & HETR $-\mathrm{R}-\mathrm{A}$ & RTEU-R-A \\
\hline 1. & Economic Value Added - EVA & $99,298,197$ & $(5,123,506)$ & $6,772,933$ & $(9,858,252)$ \\
\hline 2. & Economic Value - EV & $510,467,706$ & $105,406,293$ & $97,618,498$ & $80,917,607$ \\
\hline 3. & Net Debt & $95,920,841$ & $8,239,983$ & $12,938,028$ & $32,223,755$ \\
\hline 4. & Economic Value/Market Capitalization & 1.2314 & 1.0848 & 1.1528 & 1.6618 \\
\hline 5. & Total Liabilities/Economic Value & 0.2170 & 0.0810 & 0.1474 & 0.4241 \\
\hline 6. & Net Debt/Economic Value & 0.1879 & 0.0782 & 0.1325 & 0.3982 \\
\hline 7. & Economic Value/EBIT & 8.0025 & 16.4037 & 14.4070 & 155.6386 \\
\hline 8. & Market Capitalization & $414,546,865$ & $97,166,310$ & $84,680,470$ & $48,693,852$ \\
\hline \multirow[t]{3}{*}{9.} & Net Income/Net Loss & $55,403,191$ & $6,218,284$ & $5,928,908$ & $1,024,844$ \\
\hline & & \multicolumn{4}{|c|}{2011} \\
\hline & Financial Ratios & TLKM $-\mathrm{R}-\mathrm{A}$ & HEDR - R-A & HETR $-\mathrm{R}-\mathrm{A}$ & RTEU-R-A \\
\hline 1. & Economic Value Added - EVA & $96,732,339$ & $(10,439,975)$ & $1,297,777$ & $(3,898,681)$ \\
\hline 2. & Economic Value - EV & $480,868,656$ & $101,584,105$ & $94,027,906$ & $79,339,712$ \\
\hline 3. & Net Debt & $66,321,791$ & $4,417,795$ & $9,347,436$ & $30,645,860$ \\
\hline 4. & Economic Value/Market Capitalization & 1.1600 & 1.0455 & 1.1104 & 1.6294 \\
\hline 5. & Total Liabilities/Economic Value & 0.2110 & 0.0623 & 0.1049 & 0.4416 \\
\hline 6. & Net Debt/Economic Value & 0.1379 & 0.0435 & 0.0994 & 0.3863 \\
\hline 7. & Economic Value/EBIT & 7.6028 & 191.6005 & 282.0791 & 11.8606 \\
\hline 8. & Market Capitalization & $414,546,865$ & $97,166,310$ & $84,680,470$ & $48,693,852$ \\
\hline 9. & Net Income/Net Loss & $54,920,372$ & 608,625 & 79,028 & $5,544,367$ \\
\hline
\end{tabular}

Table 6: Calculation of Economic Value Added and Other Financial Indicators for Selected Shares

Source: www.blberza.com (Calculation by Author) 
Hydroelectric power plants on the Drina River, Visegrad (HEDR-R-A) and Ugljevik ad (RTEU$\mathrm{RA}$ ), were not able to compensate for the opportunity cost of funds invested despite a positive net financial result in 2011.

Since the limited companies in 2011 achieved positive financial results but were not able to cover the opportunity cost, they could provide for a better way to utilise their capital. More companies account the added economic value that determines salaries of their managers.

\section{CONCLUSION}

Performance value measures were developed in order to obtain internal performance measures that would have a higher correlation with market performance, i.e. target function by maximizing a value for shareholders. The foundation of performance value measures is the idea that a company should provide a higher return on invested capital than the cost of capital and maintain a positive range of performance.

The aim of calculating economic value added of a company presents quantification of effects of changes in the book value of the equipment and reduction of its value to its recoverable amount. If consequences of changes in the book value of tangible fixed assets are changes in inflow and outflow of economic benefits from the company, then the effects of changes are only in the field of information on the operations and financial position of the company. On the other hand, if a change in the book value of property causes changes in the inflow and outflow of economic benefits from a company, it has an effect on the economic value of the company.

As already stated, economic value added is calculated by subtracting tax deductible cost of capital from net operating income, so that the book value of equity in income has a significant effect on the economic value added. Given that the value of equity is in the balance of net assets, the cost of capital in the calculation of economic value added is not completely reliable if the book value of the assets in the balance is unreliable. Therefore, no economic value added of a company is entirely acceptable if financial statements contain unreliable data on assets and equity.

A model to calculate the cost of capital was built on the emerging market and it is applicable in such conditions. In terms of an undeveloped capital market such as the markets in the region, the applicabil- ity of EVA as a measure of business performance is questionable because there are no institutions that would provide statistical data related to the market risk premium and cost of capital. However, the concept of economic value added in the future will have an increasing importance given the completion of the privatization process and EU accession. Therefore, it is necessary to shed light on this concept, i.e. understand its limitations as interpreted by a company's value and other valuation methods.

\section{REFERENCE}

Belak, V. (1997). The added value of capital invested in the company. Zagreb: RRIF Plus.

Belak, V. (2002). Ekonomska dodana vrijednost (EVA) i tržišna dodana vrijednost (MVA) kao mjere performanse tvrtke. Računovodstvo, revizija i financije, 4, 42-47. (in Croatian)

Bodie, Z., Kane, A., \& Marcus, A.J. (2006). Essentials of Investments. Boston: McGraw-Hill.

Centralana banka Bosne I Hercegovine. (2011). Godišnji izveštaj 2011. Retrieved December 10, 2012, from http://www.cbbh.ba/files/godisnji_izvjestaji/2011/ GI_2011_bs.pdf (in Serbian)

Damodaran, A. (2002). Investment valuation: Tools and techniques for determining the value of any asset $\left(2^{\text {nd }}\right.$ ed.). New York: John Wiley and Sons.

Komisija za hartije od vrijednosti Republike Srpske. (2011). Izvještaj o radu i stanju na tržištu hartija od vrijednosti za 2011. godinu. Retrieved December 10, 2012, from http://www.secrs.gov.ba/Izvjestaji/2011. pdf (in Serbian)

Komisija za vrijednosne papire Federacije Bosne i Hercegovine. (2011). Izvještaj o radu za 2011. Retrieved December 10, 2012, from http://www.komvp.gov.ba/ site/index.php/o-komisiji/izvjestaji-komisije/item/izvjestaj-komisije-2011 (in Serbian)

Narayanan, M.P., \& Nanda, V.K. (2007). Financije za strateško odlučivanje: što nefinancijski menadžeri trebaju znati. Zagreb: Mate. (in Croatian)

Pejić-Bach, M., et al. (1997). Financiranje poslovanja $i$ projekata u kompjutorskom okruženju. Zagreb: RRIF Plus. (in Croatian)

Pike, R., \& Neale, B. (2009). Corporate Finance and Investment (6th ed.). Harlow: Financial Times Prentice Hall.

Rappaport, A. (1998). Creating shareholder value: A guide for managers and investors ( $1^{\text {st }}$ ed.). New York: Free Press. 
Rodić, J., \& Filipović, M. (2010). Procena vrednosti preduzeća. Belgrade: Asimex. (in Serbian)

SASE: The Sarajevo Stock Exchange. (2011). Godišnje statistike SASE za 2011. godinu. Retrieved December 10, 2012, from http://195.222.43.81/sase-final/language/hr-HR/Izvje\%C5\%A1taji/Izvje\%C5\%A1taji_o_trgovanju/Polugodi\%C5\%A1nji_i_Godi\%C5\%A1nji_ izvje\%C5\%A1taji/Vijest/1249/categoryId/11/ Godisnje_statistike_za_2011_godinu.aspx (in Serbian)

Todorović, M. (2010). Poslovno i finansijsko restrukturiranje preduzeća. Beograd: Centar za izdavačku delatnost Ekonomskog fakulteta.(in Serbian).
Vukičević, M., Gregurek, M., Odobašić, S., \& Grgić, J. (2010). Financijski menadžment u MS Excelu. Zagreb: Golden marketing. (in Croatian)

Wachowicz, M.J., \& Van Horne, C.J. (2007). Osnovi finansijskog menadžmenta (12. izd.). Beograd: Data status. (in Serbian)

Wachowicz, M.J., \& Van Horne, C. J. (2008). Fundamentals of Financial Management (13th ed.). London: Prentice Hall.

\section{MOGUĆNOST PRIMENE DODATE EKONOMSKE VREDNOSTI NA TRŽIŠTU KAPITALA U REPUBLICI SRPSKOJ}

\section{Rezime:}

Efikasnost rada rukovodstva pre svega zavisi od toga koliko su poboljšane performanse preduzeća, tj. da li je povećana njegova tržišna vrednost, odnosno da li se stvara vrednost za deoničare. Računovodstvena neto dobit može da pruži delimičan odgovor na ovo pitanje zbog toga što računa sa samo jednim delom troškova kapitala, tj. sa troškovima pozajmljenog kapitala dok se cena i troškovi sopstvenog kapitala zanemaruju. Metod dodate ekonomske vrednosti uzima u obzir prosečnu cenu kapitala tj. kalkuliše sa ukupnim troškovima kako pozajmljenog tako i sopstvenog kapitala. U ovom radu se ispituje mogućnost proračuna dodate ekonomske vrednosti za pojedine akcije u okviru berzanskog indeksa Republike Srpske (BIRS).

\section{Ključne reči:}

dodata vrednost za akcionare, dodata ekonomska vrednost, trošak kapitala, tržište kapitala. 